\title{
STUDIES ON THE RELATIONSHIP BETWEEN GLUCOSE OXIDATION AND INTERMEDIARY METABOLISM. III. THE INFLUENCE OF PYRIDINE NUCLEOTIDES ON PROTEIN SYNTHESIS * $\dagger$
}

\author{
By JEAN D. WILSON AND MARVIN D. SIPERSTEIN \\ (From the Department of Internal Medicine, The University of Texas Southwestern Medical \\ School, Dallas, Texas)
}

(Submitted for publication July 8, 1958; accepted August 29, 1958)

There is now abundant evidence that in many animal tissues glucose can be oxidized by two biochemical routes-the Embden-Meyerhof pathway and the hexosemonophosphate shunt. A number of investigators have described the enzymatic steps $(3,4)$ as well as the quantitative significance $(5)$ of these two routes of glycolysis. Studies in this laboratory have recently been concerned with the role of glycolysis, and particularly of the hexosemonophosphate shunt, in regulating the various synthetic processes of the animal cell. Previous reports have dealt with the relationship between glycolysis and fatty acid and cholesterol synthesis (6-8).

Glucose oxidation is also known to have a profound effect on protein metabolism. While marked restriction of caloric intake both in man and animals results in accelerated protein wastage, the administration of carbohydrate alone to such subjects causes a marked diminution of this nitrogen loss. This capacity of carbohydrate to spare protein cannot be a consequence simply of added calories; the amount of carbohydrate required is trivial, and, moreover, similar amounts of fat are relatively ineffectual in this regard (9). It is obvious, therefore, that carbohydrate and protein metabolism are intimately interlinked; yet the mechanism whereby this articulation is accomplished remains obscure.

We have previously postulated on theoretical grounds that this influence of carbohydrate on protein metabolism is mediated by the cofactors generated by the hexosemonophosphate shunt (10),

* This work was presented at the meeting of the Society for Clinical Investigation, May 5, 1958, and has been published in abstract form $(1,2)$.

$\dagger$ These studies were supported in part by grants from the National Heart Institute, United States Public Health Service, and the Dallas Heart Association. and evidence has recently been presented that these cofactors may in fact play a role in the regulation of protein synthesis $(1,2)$. The purpose of the present paper is to present in detail these studies on a possible mechanism for the proteinsparing effect of glucose.

\section{EXPERIMENTAL PROCEDURE}

Treatment of animals. Male rats of the Long-Evans strain, weighing from 150 to $250 \mathrm{Gm}$., were used throughout this study. The animals were fed three different diets. One group was allowed free access to Purina Laboratory Chow prior to the time of death. Two other groups were placed in restraining cages and given ad libitum a 25 per cent protein diet ${ }^{1}$ or a protein-free diet ${ }^{1}$ for 48 to 72 hours prior to death. These variations in diet were not found to produce differences in the rates of protein synthesis by rat liver homogenates in the experiments reported here.

Preparation of homogenates and incubation procedure. The rats were stunned by a blow on the head and exsanguinated by cutting their throats. The livers were perfused through the portal vein with $15 \mathrm{ml}$. of an ice cold sucrose-electrolyte buffer ( $\mathrm{pH}$ 7.8) described by Zamecnik and Keller (11). The livers were then excised, placed in cold buffer, and allowed to cool; they were weighed and transferred to a Dounce homogenizer to which was added a volume of sucrose-electrolyte buffer equal to the weight of the liver. The livers were then homogenized using four slow strokes with each of two plungers, the tightest of which had a clearance of $1 \mathrm{~mm}$.

1 The composition of the 25 per cent protein diet was as follows : glucose, 67 per cent ; casein, 25 per cent; HawkOser salt mixture, 7 per cent; and vitamins per 1,000 $\mathrm{Gm}$. of diet-inositol, $500 \mathrm{mg}$.; folic acid, $10 \mathrm{mg}$.; $0.1 \mathrm{ml}$. oleum percomorphum containing vitamin $A, 6,000$ units; vitamin $D, 850$ units; and one bottle of Folbesyn (Lederle) containing thiamine, $10 \mathrm{mg}$.; riboflavin, $10 \mathrm{mg}$.; sodium pantothenate, $10 \mathrm{mg}$; niacinamide, $50 \mathrm{mg}$.; pyridoxine, $5 \mathrm{mg}$.; B-12, 15 mg.; and ascorbic acid, $300 \mathrm{mg}$. The composition of the protein-free diet was the same as the 25 per cent protein diet except that it contained: glucose, 80 per cent; corn oil, 15 per cent; Hawk-Oser salt mixture, 5 per cent; and no casein. 


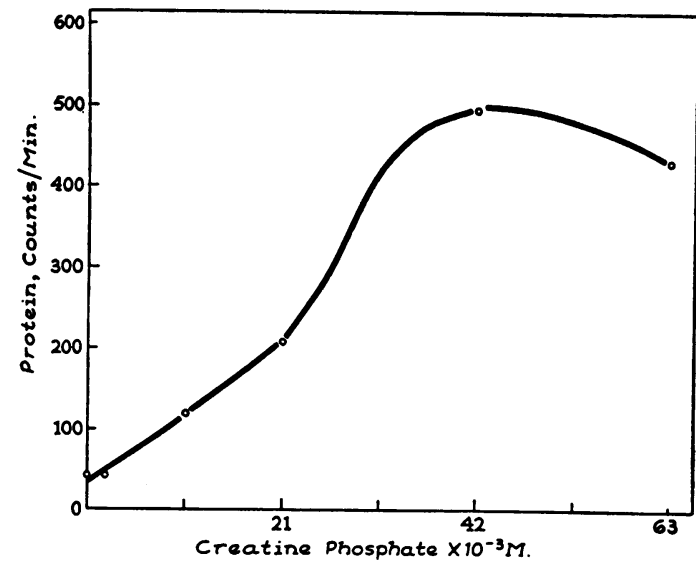

Fig. 1. Influence of ATP-Generating System on Protein Synthesis

The entire procedure was carried out in a room maintained at $5^{\circ} \mathrm{C}$. The resulting homogenate was centrifuged at $800 \times \mathrm{G}$ for 10 minutes at $-1^{\circ} \mathrm{C}$. to remove intact cells and nuclei, and the supernatant, containing the remainder of the cellular components, was used in these experiments.

One ml. aliquots of the homogenate were placed in centrifuge tubes, and substrate, coenzymes, water and acetate-1- $\mathrm{C}^{16}$ or DL-valine-1- $\mathrm{C}^{14}$ were added to give a constant volume. The flasks were gassed with 95 per cent oxygen-5 per cent carbon dioxide for 10 seconds, sealed with serum caps, and incubated at a $30^{\circ}$ angle in a Dubnoff metabolic shaker for 45 minutes at $37.5^{\circ} \mathrm{C}$.

Analytical methods. Protein was purified by a modification of the method described by Littlefield, Keller, Gross and Zamecnik (12). At the end of the incubation the serum caps were removed. The protein was precipitated, centrifuged and resuspended three times with $5 \mathrm{ml}$. of 10 per cent trichloracetic acid. The protein-trichloracetic acid mixture was then heated to $90^{\circ} \mathrm{C}$. in a water bath for 15 minutes (13), following which it was cooled, centrifuged and decanted. The precipitate was then washed two times with $8 \mathrm{ml}$. alcohol-ether-carbon tetrachloride $(2: 2: 1)$ by shaking the capped centrifuge tubes for five minutes on an International Bottle Shaking Machine. The suspension was again centrifuged and the supernatant decanted. Five ml. $1 \mathrm{~N} \mathrm{NaOH}$ was then added to the precipitate, and the opalescent solution was warmed to $40^{\circ} \mathrm{C}$. for 30 minutes (14). The protein was then reprecipitated by the addition of $2 \mathrm{ml} .10 \mathrm{~N} \mathrm{HCl}$; the tubes were centrifuged and the supernatant was decanted. The precipitate was then washed once with $5 \mathrm{ml}$. of 10 per cent trichloracetic acid and twice with $5 \mathrm{ml}$. of acetone. In these experiments the initial addition of carrier acetate and valine and the use of hot alcoholether-carbon tetrachloride were found to have no effect on the final result.

The acetone-washed precipitates (weighing approxi-

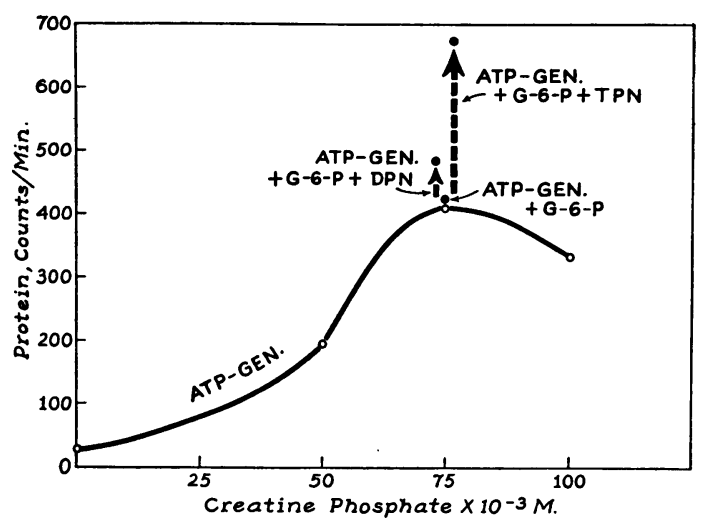

Fig. 2. Influence of TPN and DPN on Protein SYNTHESIS

mately $10 \mathrm{mg}$.) were then dissolved in $1 \mathrm{ml}$. Hyamine 2 hydroxide as described by Vaughan, Steinberg and Logan (15). The Hyamine ${ }^{(B)}$ protein solution was transferred into glass vials to which was added $16 \mathrm{ml}$. of 0.4 per cent diphenyloxazole in toluene, and the radioactivity was assayed in a Packard Liquid Scintillation Counter which was set at 1,120 volts in order to minimize the quenching of counts.

To determine the location of the label in the protein end-product, $\mathrm{N}$-terminal amino acids were separated from the protein as their dinitrophenyl derivatives as described by Porter (16). The protein was suspended in $1 \mathrm{ml}$. 5 per cent $\mathrm{NaHCO}_{3}$. Two ml. of 10 per cent fluorodinitrobenzene in ethanol was added, and the mixture was shaken on an International Bottle Shaking Machine for two hours. This solution was centrifuged, and the precipitate was washed two times each with water, ethanol, and ether and air-dried in a vacuum oven. The dinitrophenyl-protein was then hydrolyzed in $5.7 \mathrm{~N} \mathrm{HCl}$ by heating in an autoclave at $120^{\circ} \mathrm{C}$. and 15 pounds pressure for four hours. The protein hydrolysate was extracted three times with ethyl ether. The ethyl ether extracts were combined, taken to dryness, and dissolved in a few drops of ethanol. Aliquots of the ether extract and the protein hydrolysate were then mounted at "zero mass" on stainless steel planchettes and' assayed for radioactivity in a Nuclear Chicago flow counter equipped with a micromil window.

\section{RESULTS}

\section{Infuence of pyridine nucleotides on protein syn- thesis from acetate}

The results of studies on the effects of pyridine nucleotides on protein synthesis are shown in

2 Hyamine $10 \mathrm{X}$ is the trade name for para diisobutyl cresoxy ethoxy ethyl dimethyl benzyl ammonium chloride monohydrate which was purchased from The Rohm and Haas Company. 
INFLUENCE OF PYRIDINE NUCLEOTIDES ON PROTEIN SYNTHESIS

TABLE I

The influence of pyridine nucleotides on protein synthesis from acelate-1-C ${ }^{14}$ in ral liver homogenates *

\begin{tabular}{lccccc}
\hline \hline \multirow{2}{*}{$\begin{array}{c}\text { Additional substrate } \\
\text { and/or cofactors }\end{array}$} & \multicolumn{5}{c}{ Acetate-1-Cis converted to protein (cpm) } \\
\cline { 2 - 6 } & Exp. 1 & Exp. 2 & Exp. 3 & Exp. 4 & Exp. 5† \\
\hline None & 180 & 50 & 25 & 30 & 90 \\
G-6-P & 123 & 106 & 33 & 23 & 71 \\
G-6-P + TPN & 665 & 141 & 147 & 95 & 335 \\
G-6-P + DPN & 612 & 101 & 83 & 56 & 243 \\
G-6-P + TPN + DPN & 506 & 183 & & 93 & 242 \\
\hline
\end{tabular}

* Rats in Experiment 1 fed Purina Laboratory Chow; rats in Experiments 2 through 5 fed 25 per cent protein diets. For details see text.

Concentration of additions:

Experiments 1 and 5: G-6-P, $12 \times 10^{-3} \mathrm{M}$; DPN and TPN, $0.5 \times 10^{-3} \mathrm{M}$; creatine phosphate, $85 \times 10^{-3} \mathrm{M}$; ATP, $1.7 \times 10^{-3} \mathrm{M}+2 \mu \mathrm{c}$. acetate-1-C 14 to make a final volume of $2.1 \mathrm{ml}$.

Experiment 2: G-6-P, $14 \times 10^{-3} \mathrm{M} ; \mathrm{DPN}$ and TPN, $0.5 \times 10^{-3} \mathrm{M}$; creatine phosphate, $97 \times 10^{-3} \mathrm{M}$; potassium acetate, $2.7 \times 10^{-3} \mathrm{M}$; ATP, $1.9 \times 10^{-3} \mathrm{M}+2 \mu \mathrm{c}$. acetate-1-C to make a final volume of $1.8 \mathrm{ml}$.

Experiments 3 and $4: \mathrm{G}-6-\mathrm{P}, 8 \times 10^{-3} \mathrm{M}$; DPN and TPN, $0.6 \times 10^{-3} \mathrm{M}$; creatine phosphate, $112 \times 10^{-3} \mathrm{M}$; potassium acetate, $3.1 \times 10^{-3} \mathrm{M} ; \mathrm{ATP}, 2.2 \times 10^{-3} \mathrm{M}+2 \mu \mathrm{c}$. acetate-1-C ${ }^{14}$ to make a final volume of $1.6 \mathrm{ml}$.

$\dagger$ Alloxan-diabetic rats.

Table I. Glucose-6-phosphate served as the substrate in these experiments, and as indicated in Table I the addition of this compound alone had no stimulatory effect on protein synthesis in four out of the five experiments. On the other hand, the addition of either diphosphopyridine nucleotide (DPN) or triphosphopyridine nucleotide (TPN) in every case caused a definite stimulation of protein synthesis. It should be noted that in each of the five experiments the addition of TPN produced a greater increase in the synthesis of protein than did DPN. These effects were not additive in that a combination of TPN and DPN did not significantly enhance protein synthesis above that obtained with TPN alone. In a single experiment protein synthesis in homogenates obtained from the livers of alloxan diabetic rats was studied; the results were identical to those obtained in the experiments on normal rats.

The influence of other glycolytic cofactors upon protein synthesis from acetate

A previous study has demonstrated that glucose oxidation may be selectively stimulated down either the hexosemonophosphate shunt or the EmbdenMeyerhof pathway by the addition of TPN or DPN, respectively (17). Thus, it was possible that the effects of the pyridine nucleotides on protein synthesis observed here might simply be the passive consequence of the enhanced production of either adenosine triphosphate (ATP) or guano- sine triphosphate (GTP), two cofactors previously shown to stimulate protein synthesis $(11,18)$.

To resolve this question the effects of ATP and GTP, both alone and in the presence of added pyridine nucleotide, were examined. Figure 1 shows the influence of an ATP-generating system, creatine phosphate plus ATP, on protein synthesis in the rat liver system studied here. As has been previously noted by Zamecnik and Keller (11), increasing concentrations of creatine phosphate produces an increasing stimulation of protein synthesis. This effect is seen to reach a plateau in the experiment shown in Figure 1 at approximately a 40 to $45 \mu \mathrm{M}$ concentration of creatine phosphate, after which there is a slight decrease in the rate of protein synthesis with increasing concentrations of creatine phosphate.

It is apparent therefore that the influence of the pyridine nucleotides upon protein synthesis could simply be due to increased ATP generation. In order to establish whether the stimulation of protein synthesis by TPN and DPN is in fact independent of ATP generation, the influence of the pyridine nucleotides on protein synthesis was determined during the maximal enhancement of protein synthesis by ATP. As is illustrated in Figure 2, if G-6-P and TPN were added to a homogenate at the point on the curve of creatine phosphate stimulation at which protein synthesis was maximal, a twofold increase in protein synthesis was produced. G-6-P plus DPN produced 


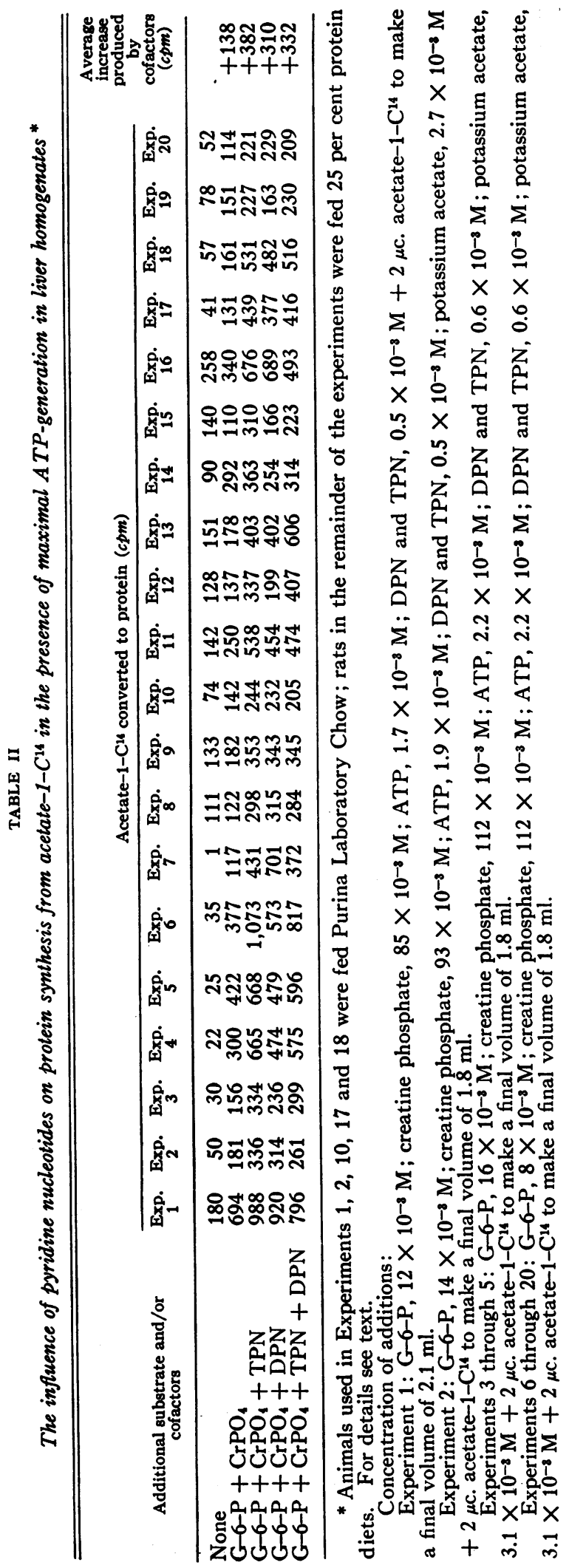

a lesser increase in protein synthesis while G-6-P alone caused no effect.

In Table II are listed the results of 20 similar experiments in which TPN and DPN were added to systems in which ATP generation was maximal. In each of these experiments the addition of the pyridine nucleotides to the systems containing glucose-6-phosphate and creatine phosphate resulted in a further increase in protein synthesis. Moreover, in 10 of the experiments the effect of TPN was definitely greater than that of DPN. In only 1 experiment was the effect of DPN greater, and in the remaining 9 experiments the stimulatory effects of TPN and DPN were comparable: In all but one experiment the effects of TPN and DPN were not additive.

To determine whether the influence of pyridine nucleotides on protein synthesis was also independent of enhanced GTP generation, another series of experiments was performed (Figure 3 ). Increasing concentrations of GTP were added to a system in which creatine phosphate concentration was maximal. As in the case of ATP, at near optimal levels of GTP, TPN and DPN enhanced protein synthesis still further. The results of four such experiments are given in Table III. GTP consistently enhanced protein synthesis above levels attainable with maximal ATP generation, and in each instance the addition of pyridine nucleotide produced still greater protein synthesis than was attainable with GTP. In two of the experiments the effect of TPN was greater than that of DPN. In the other experiments TPN and DPN had similar effects.

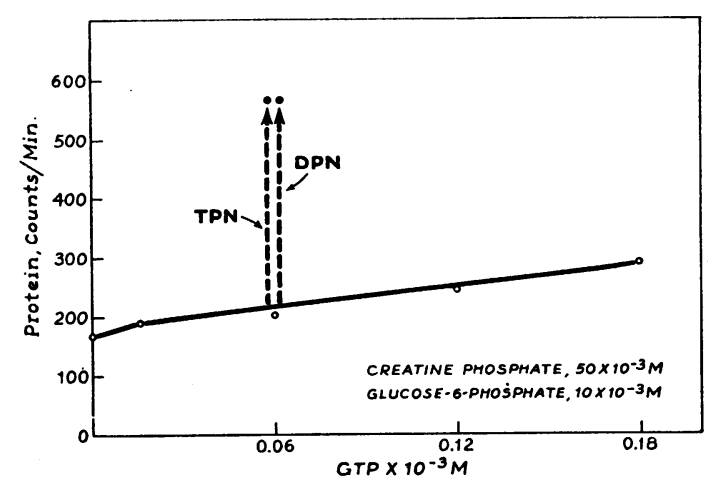

Fig. 3. Influence of GTP, TPN ANd DPN ON Protein Synthesis 
TABLE III

The influence of pyridine nucleotides on protein synthesis from acetate-1-C $C^{14}$ in the presence of GTP in rat liver homogenates *

\begin{tabular}{lcccc}
\hline & \multicolumn{3}{c}{ Acetate-1-Cu converted to protein (cpm) } \\
\cline { 2 - 5 } Additional substrate and/or cofactors & Exp. 1 & Exp. 2 & Exp. 3 & Exp. 4 \\
\hline None & 41 & 57 & 52 & 0 \\
G-6-P + CrPO & 157 & 161 & 114 & 665 \\
G-6 + CrPO + GTP & 181 & 202 & 119 & 733 \\
G-P + CrPO + GTP + TPN & 302 & 576 & 159 & 561 \\
G-6-P + CrPO + GTP + DPN & 226 & 579 & 171 & 657
\end{tabular}

* Rats in Experiments 1 and 2 fed Purina Laboratory Chow; rats in Experiments 3 and 4 fed 25 per cent protein diet. For details see text.

Concentration of additions: creatine phosphate, $73 \times 10^{-3} \mathrm{M}$; TPN and DPN, $0.61 \times 10^{-3} \mathrm{M} ; \mathrm{GTP}, 0.12 \times$ $10^{-8} \mathrm{M} ; \mathrm{G}-6-\mathrm{P}, 15.2 \times 10^{-8} \mathrm{M} ; \mathrm{ATP}, 2.4 \times 10^{-8} \mathrm{M}$; potassium acetate, $3.0 \times 10^{-8} \mathrm{M}+2 \mu \mathrm{c}$, acetate-1-C $\mathrm{C}^{14}$ to make a final volume of $1.65 \mathrm{ml}$.

\section{Effect of pyridine nucleotides on protein synthesis from valine}

Because of the possibility that the effects of the pyridine nucleotides on acetate-1- $\mathrm{C}^{\mathbf{1 4}}$ incorporation into protein might not necessarily represent enhanced protein synthesis per se but rather reflect an increased incorporation of the labeled acetate into four carbon amino acid precursors, it was necessary to study the effects of TPN and DPN on the incorporation of an essential amino acid into protein. In Table IV are given the results of five experiments in which the effects of TPN and DPN on the incorporation of DL-valine-1-C ${ }^{14}$ into protein were studied. As in the case of acetate, creatine phosphate and glucose-6-phosphate produced a definite increase in protein synthesis when added to the liver system. Once again, DPN and TPN produced a further increase in protein synthesis. In two instances TPN had a greater effect than
$\mathrm{DPN}$; in the remaining three experiments there was no apparent difference between the stimulatory effects of the two pyridine nucleotides.

\section{Site of label in synthesized protein}

Since evidence has recently been presented that incorporation of labeled amino acids into protein may under some circumstances represent acylation by the amino acids rather than their actual incorporation into the peptide chain itself (19), the site of the label in proteins synthesized by the system employed here was examined.

Regenerating livers from partially hepatectomized rats were studied in order to obtain a highly active preparation. Homogenates of these livers were incubated with valine-1-C $\mathrm{C}^{14}$ and with the various combinations of cofactors described above. The isolated proteins incorporated the $\mathrm{C}^{14}$ labeled valine as shown in the second column of Table V.

TABLE IV

Influence of pyridine nucleotides on prolein synthesis from $D L$-oaline-1-C ${ }^{14}$ in rat liver homogenates *

\begin{tabular}{lccccr}
\hline \hline & \multicolumn{5}{c}{ DL-valine-1-Cu converted to protein (cpm) } \\
\cline { 2 - 6 } Additional substrate and/or cofactors & Exp. 1 & Exp. 2 & Exp. 3 & Exp. 4 & Exp. 5 \\
\hline None & 68 & 16 & 140 & 9 & 0 \\
G-6-P + CrPO & 249 & 282 & 364 & 112 & 20 \\
G-6-P + CrPO + TPN & 269 & 386 & 390 & 202 & 170 \\
G-6-P + CrPO, + DPN & 298 & 331 & 377 & 223 & 111 \\
G-6-P + CrPO + TPN + DPN & 127 & 292 & 399 & 171 & 164 \\
\hline
\end{tabular}

* Rats in Experiments 1 and 2 fed 25 per cent protein diets; rats in Experiments 3 through 5 fed protein-free diets. For details see text.

Concentration of additions:

Experiment 1: G-6-P, $16 \times 10^{-3} \mathrm{M}$; DPN and TPN, $0.6 \times 10^{-3} \mathrm{M}$; creatine phosphate, $112 \times 10^{-3} \mathrm{M}$; DL-valine, $3.1 \times 10^{-3} \mathrm{M} ;$ ATP, $2.2 \times 10^{-3} \mathrm{M}+2 \mu \mathrm{C}$. DL-valine-1-Cis to make a final volume of $1.6 \mathrm{ml}$.

Experiments 2 through 5: G-6-P, $8 \times 10^{-3} \mathrm{M} ;$ DPN and TPN, $0.6 \times 10^{-3} \mathrm{M}$; creatine phosphate, $112 \times 10^{-2} \mathrm{M}$; DL-valine, $3.1 \times 10^{-3} \mathrm{M} ; \mathrm{ATP}, 2.2 \times 10^{-8} \mathrm{M}+2 \mu \mathrm{c}$. DL-valine-1-C 14 to make a final volume of $1.6 \mathrm{ml}$. 
TABLE $v$

Distribution of $C^{14}$ in protein synthesized from $D L-v a l i n e-1-C^{14}$ in rat liver homogenates *

\begin{tabular}{lccr}
\hline \hline & \multicolumn{2}{c}{ Per cent recovered counts in: } \\
\cline { 2 - 4 } Additional substrate and/or cofactors & $\begin{array}{c}\text { DL-valine-1-Cu } \\
\text { converted to } \\
\text { protein (cpm) }\end{array}$ & $\begin{array}{c}\text { Fluorodinitro- } \\
\text { benzene } \\
\text { reacting } \\
\text { amino acids }\end{array}$ & $\begin{array}{c}\text { Protein } \\
\text { residue }\end{array}$ \\
\hline None & 161 & 3 & 97 \\
G-6-P + CrPO & 1,756 & 1 & 99 \\
G-6-P + CrPO4 + TPN & 1,925 & 1 & 99 \\
G-6-P + CrPO4 + DPN & 2,197 & 0 & 100 \\
\hline
\end{tabular}

* Partial hepatectomy performed four days prior to death. Rats fed Purina Laboratory Chow.

Concentration of additions: ATP, $2.7 \times 10^{-3} \mathrm{M} ; \mathrm{G}-6-\mathrm{P}, 8.3 \times 10^{-3} \mathrm{M}$; creatine phosphate, $53 \times 10^{-3} \mathrm{M} ; \mathrm{DPN}$ and TPN, $0.66 \times 10^{-3} \mathrm{M}+2 \mu \mathrm{c}$. DL-valine-1-C 14 to make a final volume of $1.5 \mathrm{ml}$.

The dinitrophenyl derivatives of the $\mathrm{N}$-terminal amino acids were formed and isolated. The radioactivity in this fraction was in each case negligible compared to that of the intact protein, a finding which strongly suggests that under the conditions of synthesis and isolation employed in this study the valine-C $\mathrm{C}^{14}$ was in fact incorporated into the peptide linkages of the protein.

\section{DISCUSSION}

Evidence has recently been presented that the oxidation of glucose exerts a controlling influence on both fatty acid and cholesterol synthesis, not so much by producing substrate but rather by generating the reduced pyridine nucleotides, particularly triphosphopyridine nucleotide, required for these synthetic reactions $(6-8)$. It seemed possible, therefore, that the interrelation of carbohydrate and protein metabolism might be disclosed by an examination of the relationship between protein synthesis and the cofactors generated during glucose breakdown.

In Figure 4 are shown the cofactors produced by the oxidation of glucose to pyruvate and oxalacetate. As glucose enters the cell it may be metabolized by one of two pathways. If it goes down the Embden-Meyerhof route, reduced diphosphopyridine nucleotide (DPNH) is generated, whereas oxidation by the hexosemonophosphate shunt yields reduced triphosphopyridine nucleotide (TPNH). Furthermore, glycolysis can also produce adenosine triphosphate (ATP), and if oxalacetate is formed the synthesis of guanosine triphosphate (GTP) results.

The studies reported here clearly indicate that each of the cofactors involved in glycolysis and oxalacetate formation, GTP, ATP, DPN and TPN, can exert a stimulatory effect on protein synthesis, as judged by their influence on the incorporation of acetate and valine into the protein of rat liver homogenates.

ATP and GTP have previously been shown to enhance protein synthesis in liver homogenates $(11,18)$. The most significant finding of the present study, however, was the observation that the pyridine nucleotides, DPN and TPN, probably in their reduced forms, consistently produce a stimulation of protein synthesis. This effect was particularly apparent in the case of TPN. Furthermore, the demonstration that the influence of TPN and DPN on protein synthesis is very marked even in the presence of stimulation by ATP and GTP indicates that the effects of the pyridine nucleotides on protein synthesis are independent of the role they may play in increasing ATP or GTP generation via glycolysis or the Krebs cycle.

In order to examine the mechanisms by which the various cofactors produced during glycolysis may exert their influence on protein synthesis, the known biochemical steps from the Krebs cycle intermediate, $\alpha$-ketoglutarate, to the synthesis of proteins are summarized in Figure 5. The first of these reactions consists of the fixation of ammonia with $\alpha$-ketoglutaric acid to form glutamic acid. The enzyme responsible for this reaction, glutamic dehydrogenase, is known to require either DPNH or TPNH as cofactor (20). Second, glutamate can yield other nonessential amino acids by transamination reactions. Third, glutamic acid or its 
transamination products are activated in the presence of ATP to form the adenylate derivatives of the amino acids (21). Finally, these activated amino acids are incorporated into the peptide chains of protein in a series of steps requiring ribonucleic acid and GTP (18).

It is apparent, therefore, that of the four cofactors produced during glycolysis-TPNH, DPNH, ATP and GTP-each is in fact known to be involved in the conversion of $\alpha$-ketoglutarate to proteins. That each of these cofactors may be rate-limiting for the synthesis of proteins in liver homogenates has been demonstrated by the data presented here. It is of particular interest that reduced pyridine nucleotides can exert a controlling influence upon protein synthesis since, as shown above, these cofactors are required for ammonia fixation with $\alpha$-ketoglutaric acid, the only reaction in mammalian tissues by which a net synthesis of amino acids can take place. TPNH is also involved in the fixation of $\mathrm{CO}_{2}$ to form the precursors of $\alpha$-ketoglutarate. These findings would imply that the rate of formation of amino acids themselves may be rate-limiting in the synthesis of protein.

Furthermore, it should be noted that while both TPN and DPN exerted a direct stimulatory effect on protein synthesis, TPN frequently was the more effective cofactor in this regard. This finding suggests that TPN (in the form of TPNH) may play a greater role in the regulation of protein synthesis than does DPNH. Further evidence to sup-

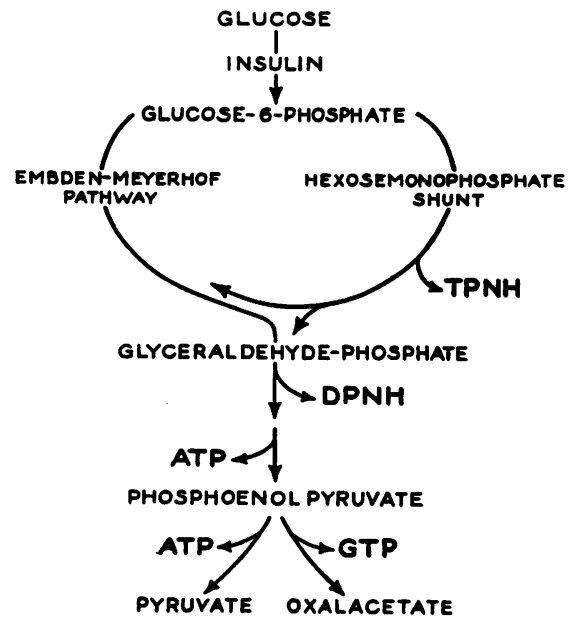

Fig. 4. Cofactors Produced during Glycolysis

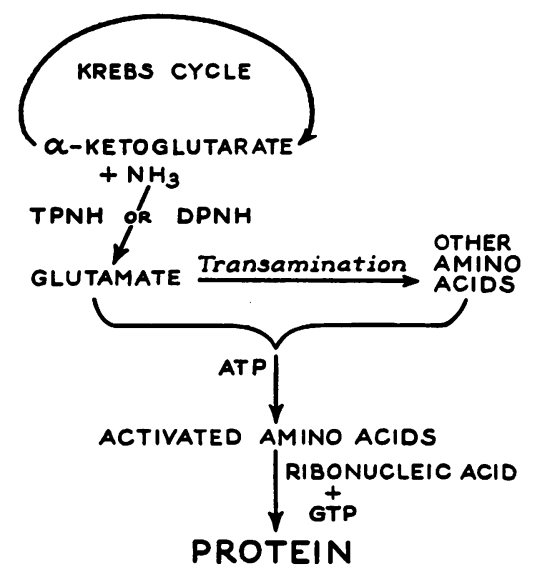

Fig. 5. Cofactors Involved in Protein Synthesis

port this view is provided by the fact that while glutamic dehydrogenase can utilize either TPNH or DPNH in glutamic acid synthesis (20), the level of DPNH in the mitochondria of the liver cell is probably too low to enable this cofactor to be an important source of hydrogen ions in the synthesis of glutamic acid (22).

The demonstration that the pyridine nucleotides can be a limiting factor in the synthesis of proteins in the system described here raises the question of the relationship between this in vitro effect and the protein-sparing effect of glucose observed in intact animals. While the obvious limitations of using the results of in vitro experiments to explain in vivo phenomena clearly apply to this problem, there is evidence that in the intact liver an increase in protein synthesis does accompany the administration of glucose (23). It seems justifiable, therefore, to hypothesize from the findings reported here that the protein-sparing effect of glucose is partially due to an increase in synthesis mediated by the cofactors generated during glycolysis and especially by the pyridine nucleotides. ${ }^{3}$ Furthermore, the fact that TPNH is more frequently the limiting factor in protein synthesis in cell-free systems suggests that the generation of this cofactor and hence the glucose oxidized via the hexosemonophosphate pathway may be of particular importance in the sparing of protein by glucose.

\footnotetext{
${ }^{3}$ It should be pointed out in this connection that the phenomena observed here are not limited to hepatic tissue in that the pyridine nucleotides have also been found to be rate-limiting in the synthesis of proteins in the regenerating dog kidney (24).
} 


\section{SUMMARY AND CONCLUSIONS}

The relationship between glycolysis and protein synthesis has been examined utilizing a cell-free system of rat liver. It was found that each of the cofactors produced by glucose oxidation can exert a stimulatory effect on the synthesis of protein, as measured by the rates of incorporation of acetate$1-\mathrm{C}^{14}$ or valine-1- $\mathrm{C}^{14}$. Of particular note was the finding that the pyridine nucleotides, and especially triphosphopyridine nucleotide, will consistently enhance protein synthesis; furthermore, this effect appears to be independent of the influence of these coenzymes on the generation of adenosine triphosphate or guanosine triphosphate. The relationship between these observations and the protein-sparing effect of glucose is discussed.

\section{ACKNOWLEDGMENT}

Grateful acknowledgment is made to Miss Margaret Joanne Guest for assistance in these experiments.

\section{REFERENCES}

1. Wilson, J. D., and Siperstein, M. D. The relation between glycolysis and protein synthesis. Clin. Res. 1958, 6, 137.

2. Wilson, J. D., and Siperstein, M. D. The mechanism of the protein-sparing effect of glucose (abstract). J. clin. Invest. 1958, 37, 943.

3. Horecker, B. L. A new pathway for the oxidation of carbohydrate. Brewer's Digest 1953, 28, 214.

4. Racker, E. Micro- and macrocycles in carbohydrate metabolism. Harvey Lect. 1957, 51, 143.

5. Wood, H. G. Significance of alternate pathways in the metabolism of glucose. Physiol. Rev. 1955, $35,841$.

6. Siperstein, M. D., and Fagan, V. M. Role of glycolysis in fatty acid and cholesterol synthesis in normal and diabetic rats. Science 1957, 126, 1012.

7. Siperstein, M. D., and Fagan, V. M. Studies on the relationship between glucose oxidation and intermediary metabolism. I. The influence of glycolysis on the synthesis of cholesterol and fatty acid in normal liver. J. clin. Invest. 1958, 37, 1185.

8. Siperstein, M. D., and Fagan, V. M. Studies on the relationship between glucose oxidation and intermediary metabolism. II. The role of glucose oxidation in lipogenesis in diabetic rat liver. J. clin. Invest. 1958, 37, 1196.

9. Munro, H. N. Carbohydrate and fat as factors in protein utilization and metabolism. Physiol. Rev. 1951, 31, 449.
10. Siperstein, M. D. Glycolytic pathways: Their relation to the synthesis of cholesterol and fatty acids. Diabetes 1958, 7, 181.

11. Zamecnik, P. C., and Keller, E. B. Relation between phosphate energy donors and incorporation of labeled amino acids into proteins. J. biol. Chem. 1954, 209, 337.

12. Littlefield, J. W., Keller, E. B., Gross, J., and Zamecnik, P. C. Studies on the cytoplasmic ribonucleoprotein particles from the liver of the rat. J. biol. Chem. 1955, 217, 111.

13. Schneider, W. C. Phosphorous compounds in animal tissues. I. Extraction and estimation of desoxypentose nucleic acid and of pentose nucleic acid. J. biol. Chem. 1945, 161, 293.

14. Winnick, T. Studies on the mechanism of protein synthesis in embryonic and tumor tissues. I. Evidence relating to the incorporation of labelled amino acids into protein structure in homogenates. Arch. Biochem. 1950, 27, 65.

15. Vaughan, M., Steinberg, D., and Logan, J. Liquid scintillation counting of $\mathrm{C}^{14}$ - and $\mathrm{H}^{3}$-labeled amino acids and proteins. Science 1957, 126, 446.

16. Porter, R. R. Determination of amino acid sequence in proteins by the fluorodinitrobenzene method in Methods in Enzymology, Vol. IV., S. P. Colowick and N. O. Kaplan, Eds. New York, Academic Press Inc., 1957, p. 221.

17. Siperstein, M. D., and Fagan, V. M. The influence of pyridine nucleotides on the pathways of glucose oxidation. Submitted for publication.

18. Keller, E. B., and Zamecnik, P. C. Effect of guanosine diphosphate on incorporation of labeled amino acids into proteins. Fed. Proc. 1955, 14, 234.

19. Castelfranco, P., Moldave, K., and Meister, A. Incorporation of the amino acid moieties of amino acid-adenylic acid anhydrides into proteins. J. Amer. chem. Soc. 1958, 80, 2335.

20. Olson, J. A., and Anfinsen, C. B. Kinetic and equilibrium studies on crystalline-1-glutamic acid dehydrogenase. J. biol. Chem. 1953, 202, 841.

21. Hoagland, M. B. An enzymic mechanism for amino acid activation in animal tissues. Biochim. biophys. Acta 1955, 16, 288.

22. Jacobson, K. B., and Kaplan, N. O. Pyridine coenzymes of subcellular tissue fractions. J. biol. Chem. 1957, 226, 603.

23. Miller, L. L., Bly, C. G., Watson, M. L., and Bale, W. F. Plasma protein synthesis observed in direct study of the liver with the aid of lysine-e- $C^{14}$. Fed. Proc. 1950, 9, 206.

24. Wilson, J. D., and Siperstein, M. D. Unpublished observations. 